\title{
Myeloid Cell Surface Antigen CD33
}

National Cancer Institute

\section{Source}

National Cancer Institute. Myeloid Cell Surface Antigen CD33. NCI Thesaurus. Code C97246.

Myeloid cell surface antigen CD33 (364 aa, $40 \mathrm{kDa}$ ) is encoded by the human CD33 gene. This protein is involved in the mediation of cell adhesion and the regulation of cellcell signaling. 